\title{
Rabbit MSTN gene polymorphisms and genetic effect analysis
}

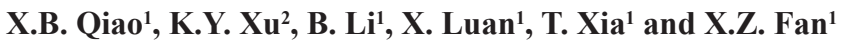 \\ ${ }^{1}$ College of Animal Science and Technology, Shandong Agricultural University, \\ Tai'an, China \\ ${ }^{2}$ Shandong University of Traditional Chinese Medicine, Jinan, China \\ Corresponding author: X.Z. Fan \\ E-mail: fanxinzhong_fxz@yeah.net
}

Genet. Mol. Res. 13 (2): 2590-2597 (2014)

Received October 30, 2013

Accepted December 10, 2013

Published April 8, 2014

DOI http://dx.doi.org/10.4238/2014.April.8.1

\begin{abstract}
We analyzed meat samples of nine pure lines of rabbit and its 37 hybrid combinations by sequencing and singlestrand conformation polymorphism techniques to explore genetic polymorphisms of all the three exon regions and part of the 5'-regulatory region of the myostatin (MSTN) gene. Thus, we detected a single nucleotide mutation $(\mathrm{T} \rightarrow \mathrm{C}$ ) on the 476 locus of the 5 '-regulatory region, but no mutation sites were detected in the exon areas. The correlation analysis showed that the mutation had some favorable genetic effects, and it resulted in increased liver weight, carcass weight, forelegs weight, back and waist weight, ham weight, and tare weight, whereas it decreased muscle drip loss and cooking loss $(\mathrm{P}<0.05)$. These results suggest that the mutations in the upstream regulatory region of the MSTN gene are beneficial to the rabbit soma development, and the mutations can be used as molecular markers for the selection of the meat quality of rabbits.
\end{abstract}

Key words: Rabbits; $M S T N$ gene; Single nucleotide polymorphism; Meat quality traits 


\section{INTRODUCTION}

Myostatin (MSTN) is a negative regulator of the muscle growth factor, which belongs to the transforming growth factor beta superfamily (McPherron et al., 1997). It is able to negatively control the growth of muscle cells by inhibiting the transcriptional activity of MyoD family members. Its expression is negatively correlated with muscle weight (Weber et al., 2005). Mutations of the MSTN gene-conserved Ribbon bases in mice and some other livestock will lead to the inactivation of the gene expression product and the loss of function in inhibiting muscle growth, which will result in excessive muscle development and expression (Lee and McPherron, 1999). Homozygote and heterozygote cattle with mutations of the MSTN gene-conserved Ribbon bases exhibit the advantage of strong muscle, birth weight increase, and obvious double-hip muscle characteristics (Casas et al., 1999). As the candidate gene in pig double-hip muscle, the MSTN gene has an important impact on the amount of lean meat and fat deposition (Sonstegard et al., 1998). The rabbit is of high quality and efficiency as a meat livestock and a common experimental animal. Therefore, the clarification of its genetic basis and regulation mechanism of skeletal muscle growth and development has an important theoretical and practical significance. However, the related research is rarely reported. Fontanesi et al. (2008) reported the only $34 \mathrm{C} \rightarrow \mathrm{T}$ point mutation in the intron of the rabbit MSTN gene. The allele frequencies in their study were 0.51 and 0.49 , and the loci can be used as molecular markers in the study of rabbit production performance (Fontanesi et al., 2008). In this experiment, the PCR-based single-strand conformation polymorphism (SSCP) technique was used to screen and sequence single nucleotide polymorphisms (SNPs) in the entire coding region and a part of the 5'-regulatory region nucleotide sequence in the rabbit MSTN gene. The aim of the study was to provide the basis for determining the mechanism of rabbit muscle growth and development, as well as the molecular breeding of rabbit meat, by performing an association analysis of the newly discovered SNPs and growth and carcass traits of rabbits.

\section{MATERIAL AND METHODS}

\section{Animal experiment and performance measurement}

The meat of specialized rabbit strains and their hybrid group, cultivated by Qingdao Kangda Rabbit Industry Development Co., Ltd. and Shandong Agricultural University, was used as the experimental material. A total of nine strains and 37 binary combinations were included, where each combination had 80-100 rabbits to participate in the fattening determination. All combinations adopted the same conditions of standard feeding and management, and the individual growth and development traits were recorded, including the body weight at 35 days (BW35), BW70, length at 70 days (BL70), and chest circumference at 70 days. On the 84th day, 410 rabbits were slaughtered and measured, and 10 to 12 rabbits were randomly selected in each combination, containing 50\% male and 50\% female rabbits. The carcass traits before slaughter included the live weight; carcass weight $(\mathrm{CW})$; dressing percentage $(\mathrm{CP})$; forelegs weight (FOW); back and waist weight (LOW); ham weight (HW); liver weight; heart, lung, and kidney weight (HLRW); head weight (HH); and tare weight (TW). Meat quality traits included the back and waist longest muscle $\mathrm{pH}$, water-holding capacity (WHC), drip loss, cooking loss (CL), cooked meat rate, and tenderness degree (Tn). The conventional nutri- 
tional content of dry matter, ash content, and protein content, and the intramuscular fat content were detected at the testing center of Qingdao Kangda Food Co., Ltd. During the slaughter, ear pliers were used to remove the small ear tissues (approximately $0.5 \mathrm{~g}$ ), which were then placed in $70 \%$ ethanol at $-20^{\circ} \mathrm{C}$ for storage.

\section{Primer design and PCR amplification}

Based on the MSTN gene sequences (Ensembl Gene ID: ENSOCUG00000012663), Primer 5.0 and Oligo 6 softwares were used to design the specific primers, which covered three exon regions and a part of the 5'-regulatory region of the total 1695-bp nucleotide sequence in the rabbit MSTN gene (Table 1).

\begin{tabular}{|c|c|c|c|c|}
\hline No. & Position & Primer sequences & Size (bp) & Annealing temperature $\left({ }^{\circ} \mathrm{C}\right)$ \\
\hline 1 & 5'-UTR + exon 1 & $\begin{array}{l}\text { F: 5'-GACAGCGAGATTCATTGTGG-3' } \\
\text { R: 5'-CCACGATCAGCATAAACAGG-3' }\end{array}$ & 286 & 60 \\
\hline 2 & Exon 1 & $\begin{array}{l}\text { F: 5'-CCTGTTTATGCTGATCGTGG-3' } \\
\text { R: 5'-TCACTGCTGTCATCCCTCTG-3' }\end{array}$ & 276 & 58 \\
\hline 3 & Intron $1+$ exon 2 & $\begin{array}{l}\text { F: 5'-GCATGCATTATCCCAATAG-3' } \\
\text { R: 5'-CCTTGTACCGTCTTTCATA-3' }\end{array}$ & 289 & 62 \\
\hline 4 & Exon 2 & $\begin{array}{l}\text { F: 5'-TGAGACCCGTGAAGACTCCTA-3' } \\
\text { R: 5'-GTTATCACTTACCAGCCCATC-3' }\end{array}$ & 281 & 60 \\
\hline 5 & Intron $2+$ exon 3 & $\begin{array}{l}\text { F: 5'-GAGCTATGAGGGGAAAATCA-3' } \\
\text { R: 5'-TCCACAGTTAGAGGGTAGCG-3' }\end{array}$ & 278 & 59 \\
\hline 6 & Exon 3 & $\begin{array}{l}\text { F: 5'-CCACTGGCCTCGTCCTAATA-3' } \\
\text { R: 5'-AAATCTCATG AGCACCCAC-3' }\end{array}$ & 285 & 60 \\
\hline
\end{tabular}

PCR amplification was performed in an Eppendorf PCR instrument. The reaction contained $2.5 \mu \mathrm{L} 10 \mathrm{X}$ buffer, $1.5 \mu \mathrm{L} 25 \mathrm{mM} \mathrm{Mg}^{2+}, 2 \mu \mathrm{L} 2.5 \mathrm{mM}$ dNTP, $0.5 \mu \mathrm{L}$ of each $20 \mathrm{pM}$ upstream primer and downstream primer, $1.0 \mu \mathrm{L}$ DNA template, $0.25 \mu \mathrm{L} 5 \mathrm{U} / \mu \mathrm{L}$ Taq DNA polymerase, and enough sterile double-distilled water to make up the reaction volume to 25 $\mu \mathrm{L}$. The PCR amplification conditions were as follows: denaturation at $95^{\circ} \mathrm{C}$ for $2.5 \mathrm{~min}$, followed by 30 cycles of denaturation at $94^{\circ} \mathrm{C}$ for $40 \mathrm{~s}$, annealing at $60^{\circ} \mathrm{C}$ for $45 \mathrm{~s}$, and extension at $72^{\circ} \mathrm{C}$ for $30 \mathrm{~s}$, and then a final extension at $72^{\circ} \mathrm{C}$ for $7 \mathrm{~min}$. The PCR product was subjected to $1.5 \%$ agarose gel electrophoresis and visualized by a gel imager.

\section{SSCP analysis}

The PCR product $(1 \mu \mathrm{L})$ was mixed with $5 \mu \mathrm{L}$ sample buffer $(98 \%$ formamide, $0.025 \%$ bromophenol blue, $0.025 \%$ xylene phthalocyanine, $10 \mathrm{mM}$ EDTA, $\mathrm{pH} 8.0$, and $10 \%$ glycerol) and denatured at $98^{\circ} \mathrm{C}$ for $10 \mathrm{~min}$, and then kept on an ice bath for $10 \mathrm{~min}$ to retain the denatured state. After the denaturation, a 12 to $15 \%$ non-denaturing polyacrylamide gel (29:1, acrylamide-bisacrylamide) was used for electrophoresis of the products, which were visualized by silver staining after running the gel for $12-14 \mathrm{~h}$ at $10 \mathrm{~V} / \mathrm{cm}$.

\section{Sequencing}

After PCR-SSCP analysis, two homozygous PCR products of each different genotype 
were selected and sent to Shanghai Biological Engineering Technology Co., Ltd. for purification and sequencing.

\section{Statistical analysis}

The GLM procedure of the SAS statistical software (SAS Institute Inc., Version 9.0) was used to perform the least-squares analysis. The Reg program was used to calculate the additive effect and dominant effect. The model adopted is as follows:

$$
Y_{\mathrm{ijk}}=\mu+G_{\mathrm{i}}+S_{\mathrm{j}}+\left(G_{\mathrm{i}} \mathrm{x} S_{\mathrm{j}}\right)+e_{\mathrm{ijk}}
$$

where $Y_{\mathrm{ijk}}$ is the phenotypic value, $\mu$ is the average, $G_{\mathrm{i}}$ is the genotype effect (including additive effect and dominant effect; $-1,0$, and 1 were used respectively in the additive effect of genotypes $\mathrm{AA}, \mathrm{AB}$, and $\mathrm{BB}$, whereas 0,1 , and 0 were used respectively on behalf of the AA, $\mathrm{AB}$, and $\mathrm{BB}$ genotypes of the dominant effect), $S_{\mathrm{j}}$ is the gender effect, $G_{\mathrm{i}} \times S_{\mathrm{j}}$ are the interaction effects of the genotype and the gender, and $e_{\mathrm{ijk}}$ is the random-residual effect.

\section{RESULTS}

\section{PCR-SSCP detection}

The PCR products in the specific amplification were of good quality, and the fragment length matched with expectation. SSCP analysis of the results showed that only the amplified fragment of the first pair of primers had the polymorphism, and this locus exhibited three genotypes (AA, AB, and BB) (Figure 1).

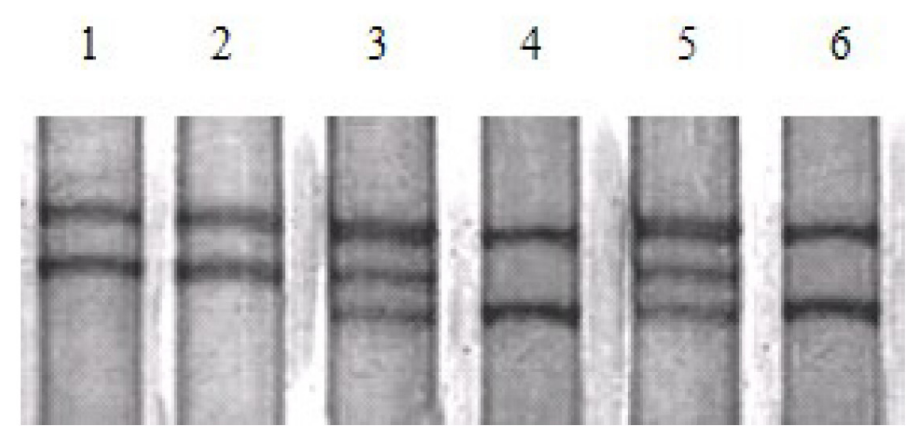

Figure 1. SSCP analysis on PCR amplification in different individuals of the MSTN gene. Lanes 1 and $2=\mathrm{AA}$; lanes 3 and $5=\mathrm{AB}$; lanes 4 and $6=\mathrm{BB}$.

\section{Sequencing of the different genotype homozygotes}

The sequencing results (Figure 2) showed that the polymorphism occurs in the 5'-regulatory region of the MSTN gene, caused by a 476 -nucleotide $\mathrm{T} \rightarrow \mathrm{C}$ point mutation. The BBtype sequence is consistent with the wild type (Ensembl Gene ID: ENSOCUG00000012663) and the AA type is defined as the mutant type. 


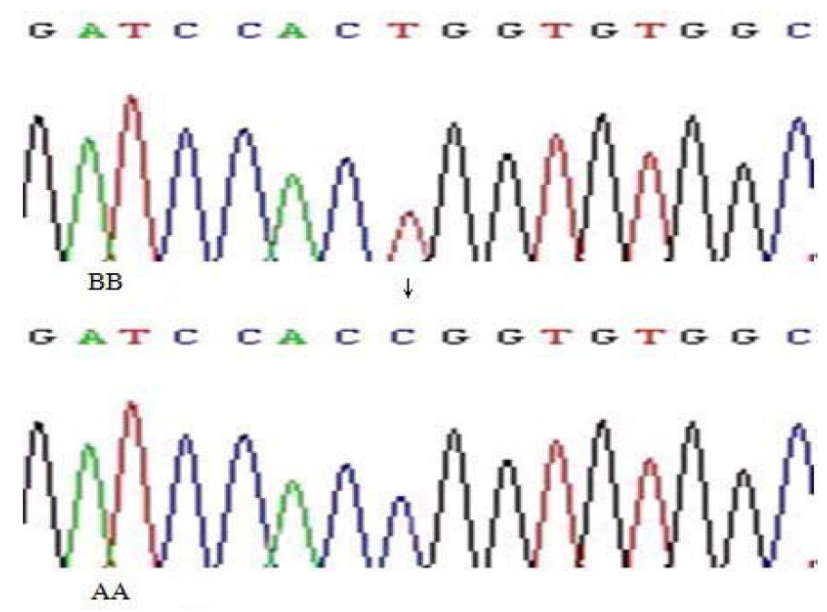

Figure 2. Sequence analysis on the isolated genotype of the MSTN gene arrow denotes substitution.

\section{Association analysis of the genotypes and growth traits}

As can be seen from Table 2, for the BW70, BW84, and chest circumference at 70 days, the difference between the AA and $\mathrm{BB}$ genotypes was significant $(\mathrm{P}<0.05)$. However, for BW35 and BL70, the difference amongst the $\mathrm{AA}, \mathrm{AB}$, and $\mathrm{BB}$ genotypes was not significant $(\mathrm{P}>0.05)$. This means that the mutation has little effect on the early growth and development of rabbits, but it does have a significant positive effect on the growth and development of the fattening period.

\begin{tabular}{|c|c|c|c|c|c|}
\hline \multirow[t]{2}{*}{ Traits } & \multicolumn{3}{|c|}{ Genotype } & \multirow[t]{2}{*}{ Additive effect } & \multirow[t]{2}{*}{ Dominant effect } \\
\hline & AA (209) & $\mathrm{AB}(162)$ & BB (39) & & \\
\hline BW35 (g) & $969.47 \pm 11.92$ & $948.29 \pm 13.55$ & $910.42 \pm 28.37$ & - & - \\
\hline BW70 (g) & $1988.85 \pm 15.84^{\mathrm{a}}$ & $2002.80 \pm 17.99^{\mathrm{a}}$ & $1903.99 \pm 37.69^{b}$ & $42.42 \pm 20.44 *$ & $56.38 \pm 27.23 *$ \\
\hline BW84 (g) & $2328.72 \pm 79.58^{\mathrm{a}}$ & $2429.30 \pm 90.41^{a}$ & $2243.30 \pm 189.3^{b}$ & $42.71 \pm 102.68$ & $143.29 \pm 136.81$ \\
\hline BL70 (cm) & $30.90 \pm 0.12$ & $30.80 \pm 0.13$ & $30.45 \pm 0.28$ & - & - \\
\hline $\mathrm{BC} 70(\mathrm{~cm})$ & $28.67 \pm 0.13^{\mathrm{a}}$ & $27.73 \pm 0.14^{\mathrm{b}}$ & $27.48 \pm 0.29^{b}$ & $0.59 \pm 0.16^{*}$ & $-0.35 \pm 0.22$ \\
\hline
\end{tabular}

\section{Genotype and slaughter trait association analysis}

Table 3 shows that some genotypes in the MSTN gene have a significant impact on the slaughter traits of CW, CP, FOW, LOW, HW, and TW ( $\mathrm{P}<0.05)$. All of these traits were significantly higher in the mutant AA genotype than the wild type, BB genotype, and heterozygous $\mathrm{AB}$ genotype $(\mathrm{P}<0.05)$. The main effect was the positive additive effect in weight gain. The AA genotype did not, however, show significant effects on HLRW and HH traits $(\mathrm{P}>0.05)$. 


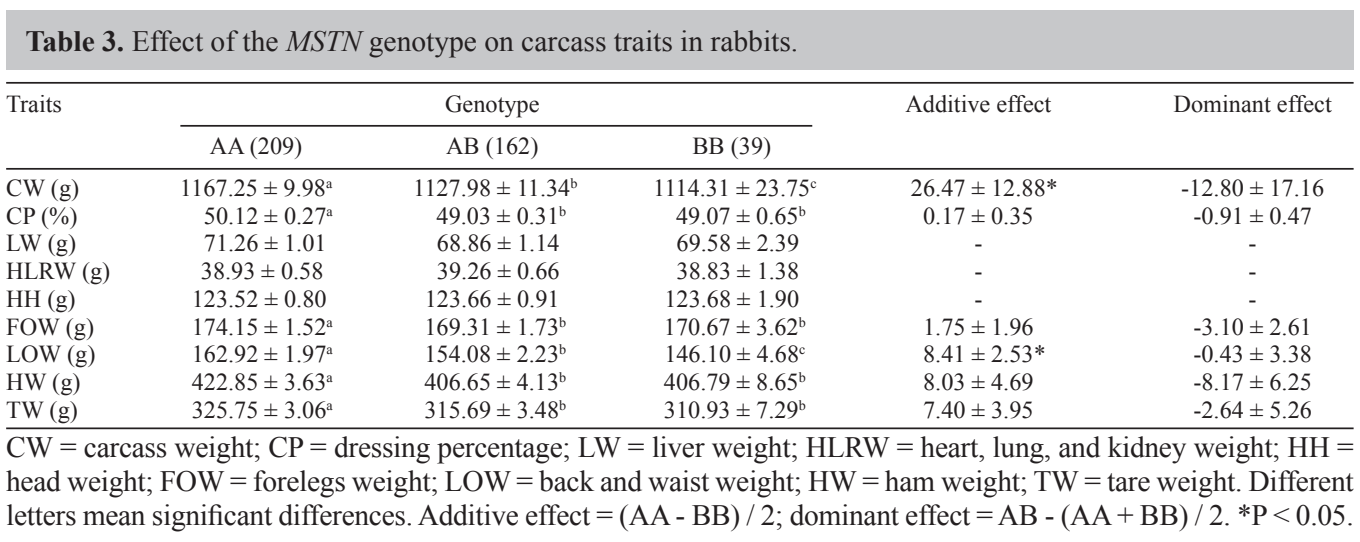

\section{Association analysis of the genotype and meat quality traits}

As shown in Table 4, the meat quality traits measured in this experiment, such as the drip loss and cooking loss differences, in the three genotypes of the MSTN gene reached a significant level $(\mathrm{P}<0.05)$. There were, however, no significant differences in the back and waist longest muscle $\mathrm{pH}$, WHP, CL, Tn, intramuscular dry matter content, ash content, protein content, and fat content.

Table 4. Effect of different genotype of MSTN on meat characteristics in rabbits.

\begin{tabular}{|c|c|c|c|c|c|}
\hline \multirow[t]{2}{*}{ Traits } & \multicolumn{3}{|c|}{ Genotype } & \multirow[t]{2}{*}{ Additive effect } & \multirow[t]{2}{*}{ Dominant effect } \\
\hline & AA (209) & $\mathrm{AB}(162)$ & BB (39) & & \\
\hline $\mathrm{pH}$ & $6.06 \pm 0.02$ & $6.07 \pm 0.02$ & $6.12 \pm 0.05$ & - & - \\
\hline WHC (\%) & $88.33 \pm 0.42$ & $87.38 \pm 0.48$ & $87.15 \pm 1.00$ & - & - \\
\hline DL $(\%)$ & $16.09 \pm 0.55^{\mathrm{a}}$ & $16.17 \pm 0.62^{b}$ & $19.89 \pm 1.29^{\mathrm{b}, \mathrm{c}}$ & $-1.40 \pm 0.70^{*}$ & $-2.32 \pm 0.94 *$ \\
\hline CL $(\%)$ & $19.57 \pm 0.35$ & $19.00 \pm 0.40$ & $18.56 \pm 0.84$ & - & - \\
\hline CR (\%) & $60.31 \pm 0.29^{a}$ & $60.77 \pm 0.32^{b}$ & $61.21 \pm 0.67^{\mathrm{b}}$ & $0.22 \pm 0.36$ & $0.68 \pm 0.49$ \\
\hline $\operatorname{Tn}(-)$ & $4.36 \pm 0.09$ & $4.20 \pm 0.11$ & $4.67 \pm 0.23$ & - & - \\
\hline DM (\%) & $24.59 \pm 0.10$ & $24.59 \pm 0.11$ & $24.77 \pm 0.24$ & - & - \\
\hline $\mathrm{CA}(\%)$ & $1.01 \pm 0.01$ & $1.03 \pm 0.01$ & $1.02 \pm 0.02$ & - & - \\
\hline $\mathrm{P}(\%)$ & $22.43 \pm 0.06$ & $22.56 \pm 0.08$ & $22.58 \pm 0.16$ & - & - \\
\hline IMF (\%) & $1.64 \pm 0.03$ & $1.67 \pm 0.03$ & $1.69 \pm 0.06$ & - & - \\
\hline
\end{tabular}

$\mathrm{pH}=$ back and waist longest muscle $\mathrm{pH} ; \mathrm{WHC}=$ water-holging capacity; $\mathrm{DL}=$ drip loss; $\mathrm{CL}=$ cooking loss; $\mathrm{CR}$ $=$ cooked meat rate; $\mathrm{Tn}=$ tenderness degree; $\mathrm{DM}=$ intramuscular dry mather content; $\mathrm{CA}=$ ash content; $\mathrm{P}=$ protein content; IMF = intra-muscular fat content. Different letters mean significant differences. Additive effect $=(\mathrm{AA}-\mathrm{BB}) /$ 2; dominant effect $=\mathrm{AB}-(\mathrm{AA}+\mathrm{BB}) / 2 . * \mathrm{P}<0.05$.

\section{DISCUSSION}

As an important gene regulator of muscle growth and development, the MSTN gene has been well studied in livestock such as cattle (Dunner et al., 1997; Grobet et al., 1998; Casas et al., 1999) and pigs (Sonstegard et al., 1998; Li et al., 2002). However, the relationship between the MSTN gene variants and the meat produced as well as the meat quality in rabbits is rarely reported. In this study, combining PCR-SSCP and DNA sequencing technologies, we used the meat of nine rabbit strains and their 37 hybrid groups to identify the $476 \mathrm{~T} \rightarrow \mathrm{C}$ muta- 
tion in the 5'-regulatory region of the gene. Through association analysis of the meat quality traits and the different genotypes of the MSTN gene, the study showed that the AA genotype was significantly different to the AB and BB genotypes, in terms of BW70, BW84 days, and chest circumference traits $(\mathrm{P}<0.05)$. The single nucleotide variation of the MSTN gene at the 5 '-regulatory region affected the cooked muscle rate, drip loss, and some carcass traits. The A allele of the MSTN gene had the effect of reducing the muscle drip loss and cooking loss, and improving the CW, FOW, LOW, HW, and TW. The results suggest that the base sites mutation in the MSTN gene is beneficial for rabbit soma development. The MSTN gene may be the major gene affecting the development and growth of the rabbit muscle or it may be linked with the main effector genes that control these traits. This mutation can be applied as molecular markers for the selection of meat quality.

The AMSTN gene variants in cows, pigs, and other livestock (McPherron and Lee, 1997; Cappuccio et al., 1998; Grobet et al., 1998) lie almost in the coding region; however, our study found that the coding region of the MSTN gene in the rabbit is highly conserved, and there are no mutation loci in the three exon regions. The only base mutation lies in the upstream regulatory region, implying that MSTN gene expression and regulation vary in different species of livestock. For example, the cattle MSTN gene is located on the 2nd autosomal (Dunner et al., 1997), and some studies have found that the cattle double-muscle trait is caused by mutations in this gene. An SNP (G $\rightarrow$ A conversion) in the MSTN gene exon 3 of Piedmont cattle causes the tyrosine to replace cysteine (Grobet et al., 1998). An 11-bp deletion of the MSTN gene was found in Belgian blue and white cattle (coding sequence $\triangle 819-829$, related with the start codon) (McPherron and Lee, 1997). Later, a single base substitution $(\mathrm{G} \rightarrow \mathrm{T})$ in locus 874 of MSTN gene exon 3 was detected in the Italian Marchigiana cattle, which causes glutamate to mutate into the stop codon, and it resulted in six of nine conserved cysteine residues to go missing (Cappuccio et al., 1998). The polymorphism between exon 2 and exon 3 of the MSTN gene in the double-hip muscle large pig was analyzed with the associated traits. It was found that the $480 \mathrm{G} \rightarrow \mathrm{T}$ mutation on exon 2 was basically irrelevant with the traits. The $1008 \mathrm{~A} \rightarrow \mathrm{G}$ mutation on exon 3 , however, was significantly correlated with the backfat thickness of the pig, but it was not significantly correlated with the lean meat percentage ( $\mathrm{Li}$ et al., 2002). Pigs with the $\mathrm{T} \rightarrow \mathrm{A}$ mutation in the 5'-regulatory region of the MSTN gene had a higher average daily gain of weight (Jiang et al., 2002). These previous findings suggest that the expression and regulation of the same gene in different species of livestock can occur in a different way, and the mechanisms of muscle growth regulation also differ among different species of livestock.

\section{ACKNOWLEDGMENTS}

Research supported by the Cooperation Project of Qingdao Kangda Rabbit Industry Development Co., Ltd. with Shandong Agricultural University (\#SDSTC07-1-073).

\section{REFERENCES}

Cappuccio I, Marchitelli C, Serracchioll A, Nardone A, et al. (1998). A G-T transversion introduces as top codon at the mh locus in hypertrophic Marchigiana beef subjects. Anim. Genet. 29 (Suppl 1): 51.

Casas E, Keele JW, Fahrenkrug SC, Smith TP, et al. (1999). Quantitative analysis of birth, weaning, and yearling weights and calving difficulty in Piedmontese crossbreds segregating an inactive myostatin allele. J. Anim. Sci. 77: 1686-1692. 
Dunner S, Charlier C, Farnir F, Brouwers B, et al. (1997). Towards interbreed IBD fine mapping of the mh locus: doublemuscling in the Asturiana de los Valles breed involves the same locus as in the Belgian Blue cattle breed. Mamm. Genome 8: 430-435.

Fontanesi L, Tazzoli M, Scotti E and Russo V (2008). Analysis of Candidate Genes for Meat Production Traits in Domestic Rabbit Breeds. 9th World Rabbit Congress, June 10-13, Verona.

Grobet L, Poncelet D, Royo LJ, Brouwers B, et al. (1998). Molecular definition of an allelic series of mutations disrupting the myostatin function and causing double-muscling in cattle. Mamm. Genome 9: 210-213.

Jiang YL, Li N, Du LX and Wu CX (2002). The relationship of swine myostatin gene 5 ' regulatory region T $\rightarrow$ A mutation and growth traits. Acta Genet. Sin. 29: 413-441.

Lee SJ and McPherron AC (1999). Myostatin and the control of skeletal muscle mass. Curr. Opin. Genet. Dev. 9: 604-607.

Li SH, Xiong YZ, Zheng R, Li AY, et al. (2002). Porcine MSTN gene polymorphism and its SNPs. Acta Genet. Sin. 29: 326-331.

McPherron AC and Lee SJ (1997). Double muscling in cattle due to mutations in the myostatin gene. Proc. Natl. Acad. Sci. U. S. A. 94: 12457-12461.

McPherron AC, Lawler AM and Lee SJ (1997). Regulation of skeletal muscle mass in mice by a new TGF-beta superfamily member. Nature 387: 83-90.

Sonstegard TS, Rohrer GA and Smith TP (1998). Myostatin maps to porcine chromosome 15 by linkage and physical analyses. Anim. Genet. 29: 19-22.

Weber TE, Small BC and Bosworth BG (2005). Lipopolysaccharide regulates myostatin and MyoD independently of an increase in plasma cortisol in channel catfish (Ictalurus punctatus). Domest. Anim. Endocrinol. 28: 64-73. 